\title{
Effect of nanosized calcium and magnesium particles on absorption in peach tree leaves
}

\author{
Jae-Ryoung Park, Yoon-Hee Jang, Il Kyung Chung, and Kyung-Min Kim
}

\begin{abstract}
Plants require a variety of elements to grow. Of these, calcium (Ca) and magnesium (Mg) play an important role in strengthening the cell wall. Although peaches (Prunus Persica) are highly preferred by consumers, they ripen quickly and become soft over a relatively short period of time after harvesting, making them difficult to transport and store. In addition, the ripening process of peaches proceeds very quickly; cell walls are weakened during maturation, and various pathogens can easily grow, causing rapid decay. Therefore, yield loss occurs during long-term storage or transport. To increase the storage period, a method to delay softening action is required. One potential means to improve firmness is to improve $\mathrm{Ca}$ and $\mathrm{Mg}$ content as these elements make up and strengthen cell walls. However, $\mathrm{Ca}$ and Mgare not readily absorbed by plants. In this study, the size of $\mathrm{Ca}$ and $\mathrm{Mg}$ particles were reduced to less than $900 \mathrm{~nm}$ via grinding and their absorption rates were evaluated in the leaves of peach trees. When plant nutrients with a small particle size by nanotechnology were sprayed on peach trees, the content of $\mathrm{Ca}$ and $\mathrm{Mg}$ was increased in the petioles, adaxial, abaxial, and leaf side. Therefore, a reduction in the particle size of $\mathrm{Ca}$ and $\mathrm{Mg}$ increases the absorption rate in peach leaves.
\end{abstract}

Key words: magnesium, calcium, wet nano grinding technology, foliar application, plant nutrients.

Résumé : Les végétaux ont besoin de divers éléments pour croître. Parmi eux, le calcium (Ca) et le magnesium (Mg) jouent un rôle important en renforçant la paroi cellulaire. Fruit de loin privilégié par le consommateur, la pêche (Prunus persica) mûrit vite et ramollit relativement peu de temps après sa cueillette, ce qui en complique le transport et l'entreposage. À cela s'ajoute la rapidité du phénomène. Durant la maturation, la paroi cellulaire s'affaiblit, ce qui permet à divers agents pathogènes d'accélérer la détérioration du fruit. Par conséquent, les pertes de rendement surviennent durant l'entreposage à long terme ou le transport. On a besoin d'une méthode pour retarder le ramollissement et prolonger l'entreposage. Une solution éventuelle pour rendre le fruit plus ferme consisterait à augmenter sa teneur en $\mathrm{Ca}$ et en $\mathrm{Mg}$, puisque ces deux éléments composent et consolident la paroi cellulaire. Malheureusement, la plante les absorbe mal. Pour leur étude, les auteurs ont réduit la taille des particules de Ca et de $\mathrm{Mg}$ à moins de $900 \mathrm{~nm}$ par meulage, puis en ont évalué le taux d'absorption par les feuilles du pêcher. Quand on pulvérise des particules dont la granulométrie a été réduite par la nanotechnologie sur les pêchers, on observe une hausse de la concentration de Ca et de $\mathrm{Mg}$ dans le pétiole ainsi que sur les faces ventrale et dorsale, et le côté de la feuille. Réduire la taille des particules de Ca et de Mg accroît donc le taux d'absorption de ces éléments par les feuilles du pêcher. [Traduit par la Rédaction]

Mots-clés : magnésium, calcium, nanomeulage humide, application foliaire, oligoéléments.

\section{Introduction}

Sixteen essential elements including carbon (C), hydrogen $(\mathrm{H})$, oxygen $(\mathrm{O})$, and nitrogen $(\mathrm{N})$ are required for plant growth (Wang et al. 2020). Crops primarily obtain $\mathrm{C}$ from atmospheric carbon dioxide $\left(\mathrm{CO}_{2}\right), \mathrm{H}$ from water, and $O$ from air; plants in return, release oxygen.

Received 1 October 2020. Accepted 11 July 2021.

J.-R. Park. Division of Plant Biosciences, School of Applied Biosciences, College of Agriculture and Life Science, Kyungpook National University, Daegu, 41566, Korea; Department of Crop Breeding, National Institute of Crop Science, Rural Development Administration, Wanju, 55365, Republic of Korea.

Y.-H. Jang and K.-M. Kim. Division of Plant Biosciences, School of Applied Biosciences, College of Agriculture and Life Science, Kyungpook National University, Daegu, 41566, Korea.

I. Kyung Chung. Institute in Natural Science Technology, Gyeongsan-si, Gyeongsanbuk-do, 38430, Korea; Department of Biotechnology, Daegu Catholic University, Gyeongsan-si, Gyeongsanbuk-do, 38430, Korea.

Corresponding authors: Il Kyung Chung (email: chungik@cu.ac.kr) and Kyung-Min Kim (email: kkm@knu.ac.kr).

(C) 2021 The Author(s). This work is licensed under a Creative Commons Attribution 4.0 International License (CC BY 4.0), which permits unrestricted use, distribution, and reproduction in any medium, provided the original author(s) and source are credited. 
The other 13 essential mineral elements are supplied directly or indirectly from the soil. Of these, $\mathrm{N}$, phosphoric acid $\left(\mathrm{H}_{3} \mathrm{PO}_{4}\right)$, potassium (K), sulfur (S), Ca, and $\mathrm{Mg}$ are classified as macroelements because crops require them in large amounts for growth (Tabak et al. 2020). Iron (Fe), Copper (Cu), zinc ( $\mathrm{Zn})$, manganese ( $\mathrm{Mn})$, boron $(\mathrm{B})$, chlorine $(\mathrm{Cl})$, and molybdenum $(\mathrm{Mo})$ are classified as microelements because of their relatively small amounts required for growth. It is important for all plants to maintain these essential elements in sufficient amounts. Calcium enhances the activity of various enzymes in the plant, promotes the synthesis of proteins, regulates the selective absorption of other ions through the cell membrane, combines with pectin compounds to maintain the rigidity of cell walls, and reduces ethylene concentration, which increases the shelf-life of fruits (Gao et al. 2019). When a plant becomes Ca deficient, leaf tips turn yellowish-white, shoot growth stops, browning gradually progresses, the plant dies, fruit decomposes from a lack of cell wall integrity, and the shelf-life is significantly reduced (Ajender and Chawla 2019).

Magnesium is an essential element of chlorophyll and plays an important role in anchoring the cell wall along with calcium (Wolf et al. 2019). Magnesium deficiency occurs most frequently after July when fruit hypertrophy commonly occurs in the leaves of fruiting areas and developing regions (Christensen et al. 1976). When Mg deficiency is severe, the leaf edges burn and chlorophyll degrades between the leaf veins (Farhat et al. 2016). Because of the aging process of the cell wall, ripening occurs very quickly and peaches tend to wither during distribution to consumers or long-distance transport, which ultimately reduces their market value (Chung et al. 2002). Therefore, it is necessary to develop methods to maintain the freshness of peaches during the production process (Girardi et al. 2005; Ruoyi et al. 2005; Lee et al. 2013). To maintain quality, it is necessary to delay the softening of peaches. This may be achieved by inhibiting the activity of enzymes related to softening or by promoting absorption and accumulation of calcium and magnesium that maintains cell wall firmness (Manganaris et al. 2005). Increasing the content of Ca and $\mathrm{Mg}$ during the cultivation process or after harvesting can improve the texture immediately after longer harvesting times (Sohail et al. 2015).

Generally, fertilizers are applied to soil when the symptoms of essential element deficiency occur. When the symptoms of deficiency of some elements appear in the plant, it is applied locally to the soil, but in this case, the effect is not applied immediately because it takes a long time to act on the plant. Therefore, fertilizer is applied to the soil in advance to prepare for the occurrence of deficiency symptoms in the following year (Yan et al. 2020; Yamane et al. 2020). This enables Ca to be absorbed by the roots and transported throughout the plant. Calcium is transported by repeated adsorption and substitution in the xylem, and its movement throughout the roots and stem is slow (Uchida 2000). Disorders related to the transport of $\mathrm{Ca}$ often occur in horticultural crops and these issues are often addressed with a Ca foliar spray (Lurie and Crisosto 2005; Kraemer et al. 2009). Foliar fertilization can solve this problem since plants can absorb nutrients through the surface of their leaves in addition to their roots. Foliar fertilization should be used for example when fertilizer applied to the soil is lost because of excessive rainfall or when plant roots do not function properly (e.g., due to pests). This is advantageous when the soil conditions are unfavorable to nutrient uptake and plants quickly respond by absorbing nutrients when there is a deficiency of trace elements (Song et al. 2006). When it rains after foliar fertilization, most of the nutrients are washed away from the leaves (Zabkiewicz 2002). In recent years, the global agricultural crop system has intensively used a large quantity of fertilizers and pesticides to achieve higher yields per unit area, and excessive fertilizer use leads to poor quality of food materials and various environmental problems (Prabakaran et al. 2018). Nanosizing plant nutrients is an innovative technology and recently, plant nutrients composed of nanoparticles have been used commercially (Krishna et al. 2001; Bansiwal et al. 2006) in agriculture. Nanoparticles with a size of 175-900 nm can be used as fertilizer for efficient plant nutrition management and reducing environmental pollution; because they have good penetration ability into plants and less time to stay in the surface area (De Oliveira et al. 2014; Mohammadinejad et al. 2016; Behboudi et al. 2019).

In this study, the absorption efficiency of nano-sized plant nutrients in peach trees was compared and analyzed. The results of this research can be effectively used to reduce excessive use of various fertilizers and herbicides as well as plant nutrients.

\section{Material and Methods}

\section{Plant material}

Peach tree (cv 'Baekhyang', Prunus persica L.) leaves were followed from May to July 2017. They were grown on commercial farms in Imgo-myeon, Yeongcheon-si, Gyeongsangbuk-do, Republic of Korea $\left(35^{\circ} 56^{\prime} 47.4^{\prime \prime} \mathrm{N}\right.$ $\left.128^{\circ} 50^{\prime} 08.8^{\prime \prime} \mathrm{E}\right)$. Peach trees were grown in soils amended as follows: a hole was made with a width of $120 \mathrm{~cm}$ and a depth of $50 \mathrm{~cm}$, and the hole was filled with decomposed granite soil. The components of decomposed granite soil are EC $0.187 \pm 0.04 \mathrm{dS} \cdot \mathrm{m}^{-1}$, pH $5.72 \pm 0.10$, T-N $2.3 \pm 0.24$, and $\mathrm{P}_{2} \mathrm{O}_{5} 13.0 \pm 0.41 \mathrm{mg} \cdot \mathrm{kg}^{-1}$. The cultivation of peaches was managed using the standard fertilization amount for peaches by the Rural Development Administration (NAAS 2010).

\section{Wet nano grinding applied to plant nutritional supplements}

Plant nutrients for foliar spraying of peach trees were prepared as a water-dispersible formulation of insoluble 
Table 1. Average particle size vs. processing time.

\begin{tabular}{lc}
\hline $\begin{array}{l}\text { Processing } \\
\text { time }(\mathrm{hrs})\end{array}$ & $\begin{array}{l}\text { Average particle } \\
\text { size }(\mathrm{nm})\end{array}$ \\
\hline 0 & $1105.0 \pm 27.1^{a}$ \\
1 & $2550.3 \pm 66.4$ \\
2 & $986.3 \pm 10.6$ \\
3 & $1084.3 \pm 48.0$ \\
4 & $1538.3 \pm 87.0$ \\
5 & $1503.0 \pm 70.8$ \\
6 & $1295.0 \pm 55.7$ \\
7 & $963.3 \pm 32.7$ \\
8 & $1073.6 \pm 78.4$ \\
9 & $838.6 \pm 65.2$ \\
10 & $918.6 \pm 12.2$ \\
11 & $597.0 \pm 17.0$ \\
\hline
\end{tabular}

${ }^{a}$ Data represent the mean \pm standard errors (SE) of five independent assays performed in triplicate; means were separated using SE.

$\mathrm{Ca}$ and Mg. The phytonutrients were generated by dispersing insoluble $\mathrm{Ca}$ and $\mathrm{Mg}$ using a nanotechnology grinding system and pulverizing the mixture for $11 \mathrm{~h}$ in a wet mill (Rotate Mill; Amstech.Co.Ltd., South Korea). The wet shredder feeds the materials/beads into a distributed bezel which collides with them. This causes the material to break down and it is passed through a screen outside of the bezel. This process was repeated to eventually produce nanosized particles (Nano Science Biotech 2016; Lee et al. 2018). The size of the $\mathrm{Ca}$ and $\mathrm{Mg}$ nanoparticles was measured using a Nano ZS (Nano ZS, Malvern, United Kingdom). The plant nutrients used in this research contained $10 \%$ of calcium acetate $\left[\mathrm{Ca}\left(\mathrm{C}_{2} \mathrm{H}_{3} \mathrm{O}_{2}\right)_{2}\right], 13 \%$ of calcium carbonate $\left(\mathrm{CaCO}_{3}\right), 2 \%$ of magnesium carbonate $\left(\mathrm{MgCO}_{3}\right), 0.5 \%$ of magnesium sulfate $\left(\mathrm{MgSO}_{4}\right), 5 \%$ of amino acids, $0.1 \%$ of boric acid $\left(\mathrm{H}_{3} \mathrm{BO}_{3}\right), 0.2 \%$ of $\mathrm{Fe}$, and $3.0 \%$ of Tween- 80 dispersed in distilled water.

\section{Nutrient spraying and sample collection}

Plant nutrients made using the nanotechnology grinding system were sprayed using an automatic sprayer (HP2010, HANIL, Geumsan, Chungnam, Republic of Korea) (Jo et al. 2020). Ten trees per treatment were sprayed at a pressure of $5.6 \mathrm{kgf} \mathrm{\textrm {cm } ^ { 2 }}$ with $500 \mathrm{~kg} \cdot \mathrm{ha}^{-1}$ diluted Ca or Mg using an automatic sprayer (HP2010, HANIL, Geumsan, Chungnam, Republic of Korea). Distilled water was sprayed with for controls. Treatments were applied on 17 May 2017 and peach leaves were harvested at $0,1,2,4$, and 8 wks after spraying. Twenty to 30 leaves from each tree from branches 1-2 $\mathrm{m}$ above the ground were selected randomly. Leaves were washed with distilled water to remove $\mathrm{Ca}$ and $\mathrm{Mg}$ remaining on the leaf surface.
Fig. 1. Analysis of $\mathrm{Ca}^{2+}$ and $\mathrm{Mg}^{2+}$ content in petioles after applying plant nutrients. Calcium appears as green and magnesium as red.

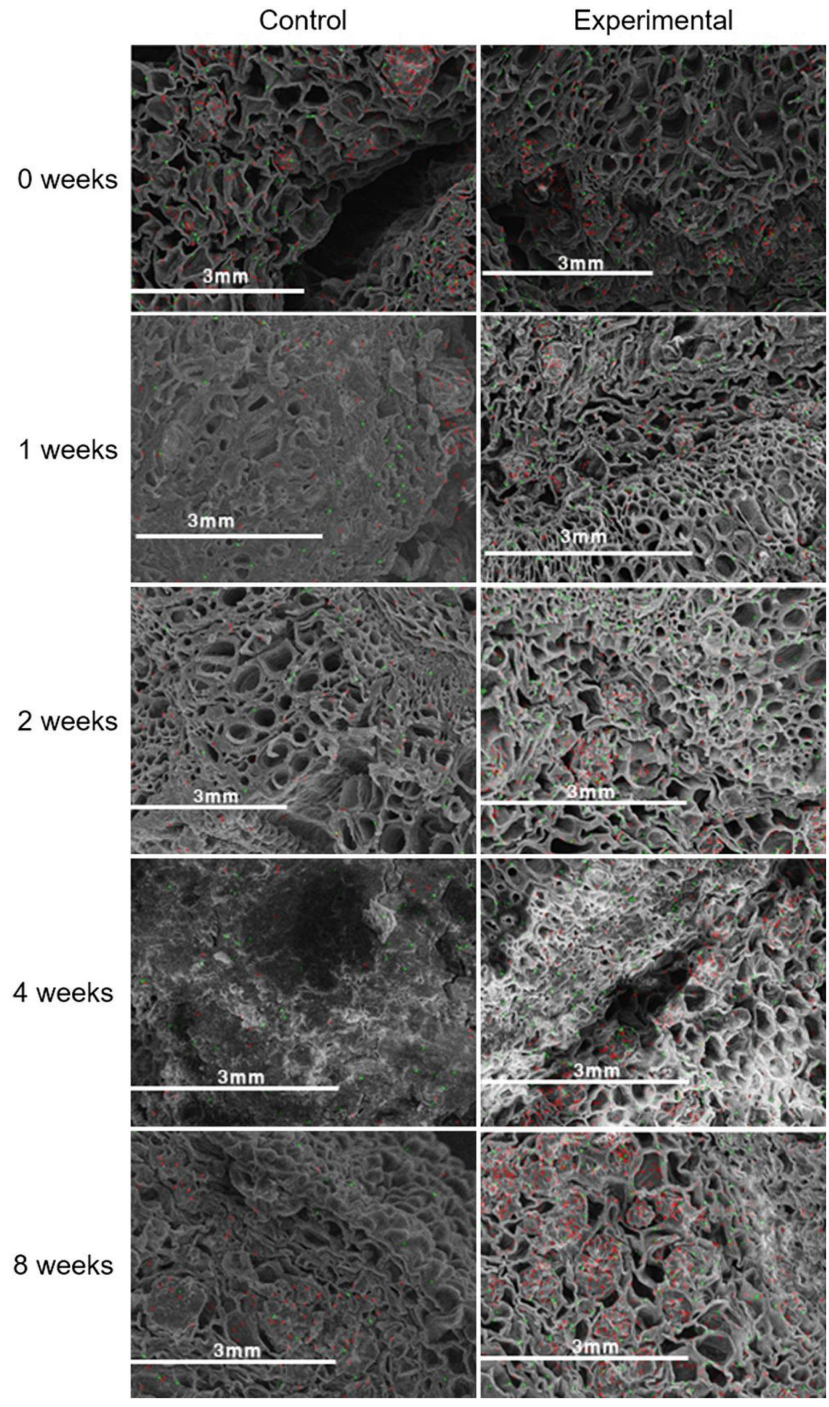

Analysis of $\mathrm{Ca}^{2+}$ and $\mathrm{Mg}^{2+}$ content in peach tree leaves

To map the $\mathrm{Ca}$ and $\mathrm{Mg}$ movements in detail, the lamina, petiole, and sides of the peach leaves were separated. Lamina were classified into adaxial and abaxial for detailed analysis. First, leaves were separated from the leaf body and petiole, fixed in a sample holder of a Cressington 108 auto scanning electron microscopy (SEM) sputter coater (Cressington Scientific Instruments Inc, Cranberry Twp, PA), and plated for approximately $55 \mathrm{~s}$ at $35 \mathrm{mbar}$. Calcium and $\mathrm{Mg}$ content of the samples was analyzed by SEM and EDS (energy dispersive spectroscopy) using a field emission SEM (JSM-6335F, JEOL, Japan) (Park et al. 2013; Yoo et al. 2016). Using SEM Ca and $\mathrm{Mg}$ are displayed in green and red, respectively, and the content was quantified by analyzing the detected color. Since this was an SEM image, the mean and standard deviations were not confirmed. EDS has 
Fig. 2. Analysis of the $\mathrm{Ca}^{2+}$ and $\mathrm{Mg}^{2+}$ content in the adaxial and abaxial surfaces of peach leaf blades after spraying with plant nutrients. Calcium appears as green and magnesium as red.

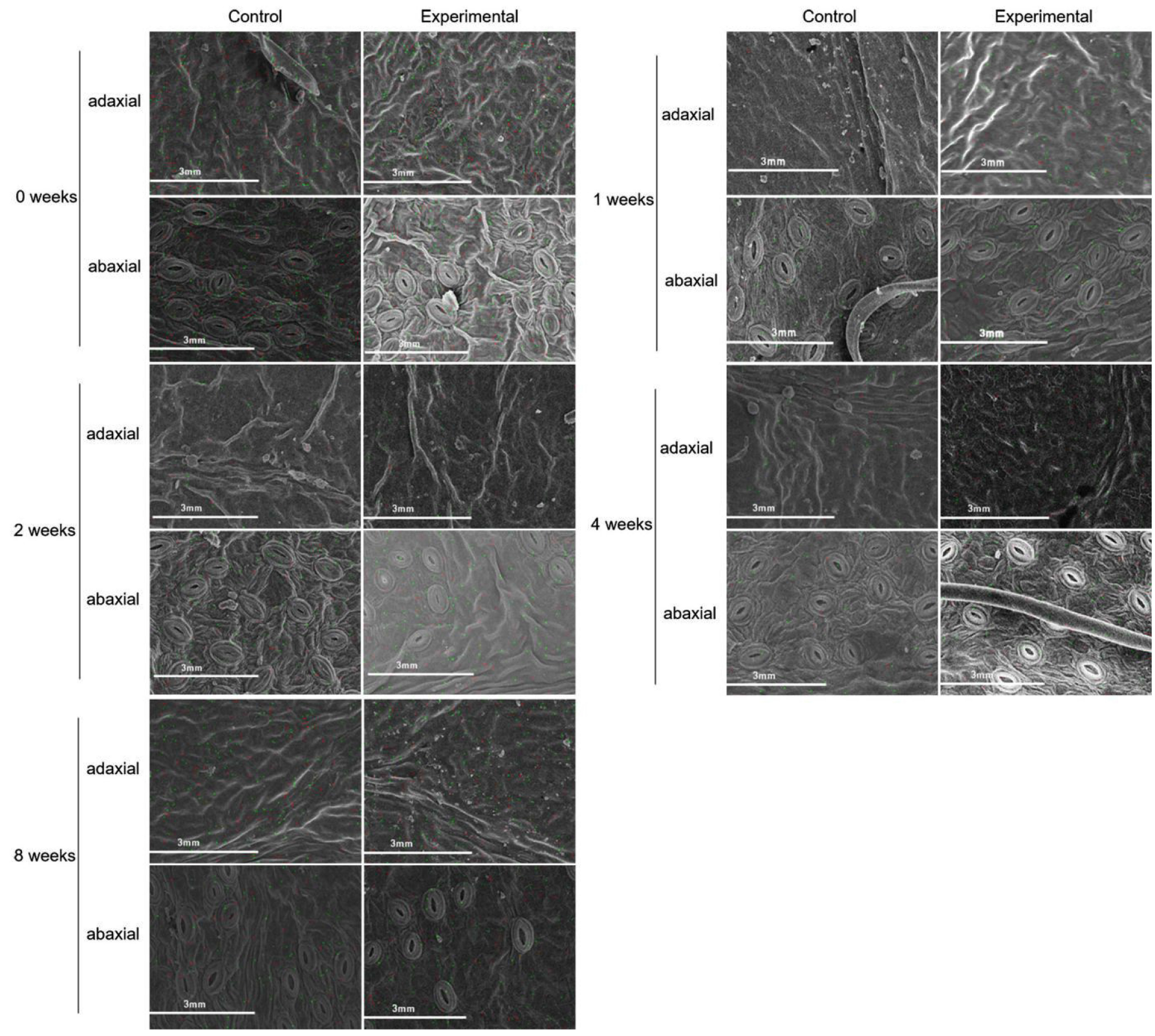

an optional feature attached to SEM that enables component analysis. After EDS analysis, the rate of increase of $\mathrm{Ca}$ and $\mathrm{Mg}$ content in the leaves was compared with the unsprayed leaves using the following formula:

$$
\text { Rate of increase }(\%)=(A-B) / B \times 100
$$

where $A$ is the $\mathrm{Ca}$ and $\mathrm{Mg}$ content (plant nutrients) of treated leaves, and $B$ is the $\mathrm{Ca}$ and $\mathrm{Mg}$ content of untreated leaves.

\section{Statistical analysis}

To determine the $\mathrm{Ca}$ and $\mathrm{Mg}$ content, 10 trees were subjected to nutrient treatment and 5 trees were

randomly selected. Then, from each tree, 30 leaves were randomly selected from the branches at a height of $1 \mathrm{~m}$ from the ground. All experimental data were replicated three times. Statistical software SPSS software (IMMSPSS Statistics, version 22, IBMSPSS Statistics, version 22, Redmond, WC, USA) was used to calculate significant differences using ordinary one-way ANOVA followed by multiple comparison with Dunnett's test.

\section{Results}

Preparation of phytonutrients by wet nano grinding

Particle size was examined at $1 \mathrm{~h}$ intervals during wet grinding (Table 1). Because of the use of Tween-80, 
particle size increased $2 \mathrm{~h}$ after using the wet mill and it increased or decreased over time. The particle size of the nutritional agents gradually decreased. Particle size was $597 \pm 17.0 \mathrm{~nm}$ after $11 \mathrm{~h}$ of operating the machine. The size of the particles was kept below $900 \mathrm{~nm}$ after at least $11 \mathrm{~h}$. This process resulted in ultrafine particles of plant nutritional agents. Therefore, the machine was run for $11 \mathrm{~h}$ for preparation of experimental nutrients.

\section{Analysis of $\mathrm{Ca}^{2+}$ and $\mathrm{Mg}^{2+}$ content in peach tree leaves Petiols}

Concentrations of $\mathrm{Ca}$ and $\mathrm{Mg}$ in petioles were compared in the control and nutrient treatments (Fig. 1 and Supplementary Table S1 ${ }^{1}$ ). For controls, after $1 \mathrm{wk}$, Ca content increased by $30.5 \pm 4.8 \%$ and $\mathrm{Mg}$ increased by $36.9 \pm 5.4 \%$ compared with week 0 . However, the absorption of $\mathrm{Ca}$ and $\mathrm{Mg}$ increased by $44.8 \pm 3.2 \%$ and $51.9 \pm 2.4 \%$, respectively, $1 \mathrm{wk}$ following treatment with phytonutrients. After $2 \mathrm{wk}$, absorption rates of Ca and $\mathrm{Mg}$ in controls were $55.4 \pm 5.7 \%$ and $62.7 \pm 2.1 \%$, respectively. However, in nutrient treatments sprayed leaves, $\mathrm{Ca}$ and $\mathrm{Mg}$ increased by $79.6 \pm 3.6 \%$ and $88.9 \pm 5.2 \%$, respectively. At week 4 in controls, Ca and $\mathrm{Mg}$ increased by $9.5 \pm 2.8 \%$ and $14.1 \pm 2.7 \%$, respectively. However, in nutrient treatments leaf $\mathrm{Ca}$ and $\mathrm{Mg}$ levels increased $79.3 \pm 4.3 \%$ and $89.8 \pm 3.1 \%$, respectively. Finally, at week 8 , Ca and $\mathrm{Mg}$ in controls increased by $9.6 \pm 1.4 \%$ and $15.3 \pm 3.4 \%$, respectively. In nutrient treatments leaf $\mathrm{Ca}$ and $\mathrm{Mg}$ content increased by $56.5 \pm 4.7 \%$ and $70.9 \pm 4.8 \%$, respectively, compared with week 0.

\section{Adaxial}

In the adaxial region, $\mathrm{Ca}$ and $\mathrm{Mg}$ in control leaves increased by $15.9 \pm 4.2 \%$ and $16.2 \pm 2.1 \%$, respectively, at week 1 compared with week 0 . However, $\mathrm{Ca}$ and $\mathrm{Mg}$ in the nutrient treatment leaf increased by $44.5 \pm 3.8 \%$ and $44.5 \pm 5.2 \%$, respectively. At week 2 , Ca and $\mathrm{Mg}$ in control groups increased by $14.3 \pm 2.9 \%$ and $14.4 \pm 3.4 \%$, whereas an increase of $37.3 \pm 2.7 \%$ and $37.5 \pm 3.2 \%$ was observed in the nutrient treatments sprayed leaves. At week 4, $\mathrm{Ca}$ and $\mathrm{Mg}$ increased by $3.1 \pm 1.4 \%$ and $3.2 \pm 1.8 \%$, respectively in control groups; treated content increased by $17.2 \pm 2.7 \%$ and $17.4 \pm 2.8 \%$, respectively. Finally, at week 8 , the content of $\mathrm{Ca}$ and $\mathrm{Mg}$ in controls increased by $1.1 \pm 0.3 \%$ and $0.9 \pm 0.7 \%$, respectively, compared with week 0; whereas in the nutrient treatment leaves, the values were $10.9 \pm 3.6 \%$ and $10.8 \pm 3.4 \%$, respectively (Fig. 2 and Supplementary Table $S 2^{1}$ ).

\section{Abaxial}

In the abaxial region, both $\mathrm{Ca}$ and $\mathrm{Mg}$ content during the investigation period was higher in the nutrient treatment leaf. At week 1, the content of Ca and $\mathrm{Mg}$ of leaf sides in controls increased by $19.6 \pm 2.7 \%$ and
Fig. 3. Analysis of the $\mathrm{Ca}^{2+}$ and $\mathrm{Mg}^{2+}$ content in petioles after spraying with plant nutrients. Calcium appears as green and magnesium as red.

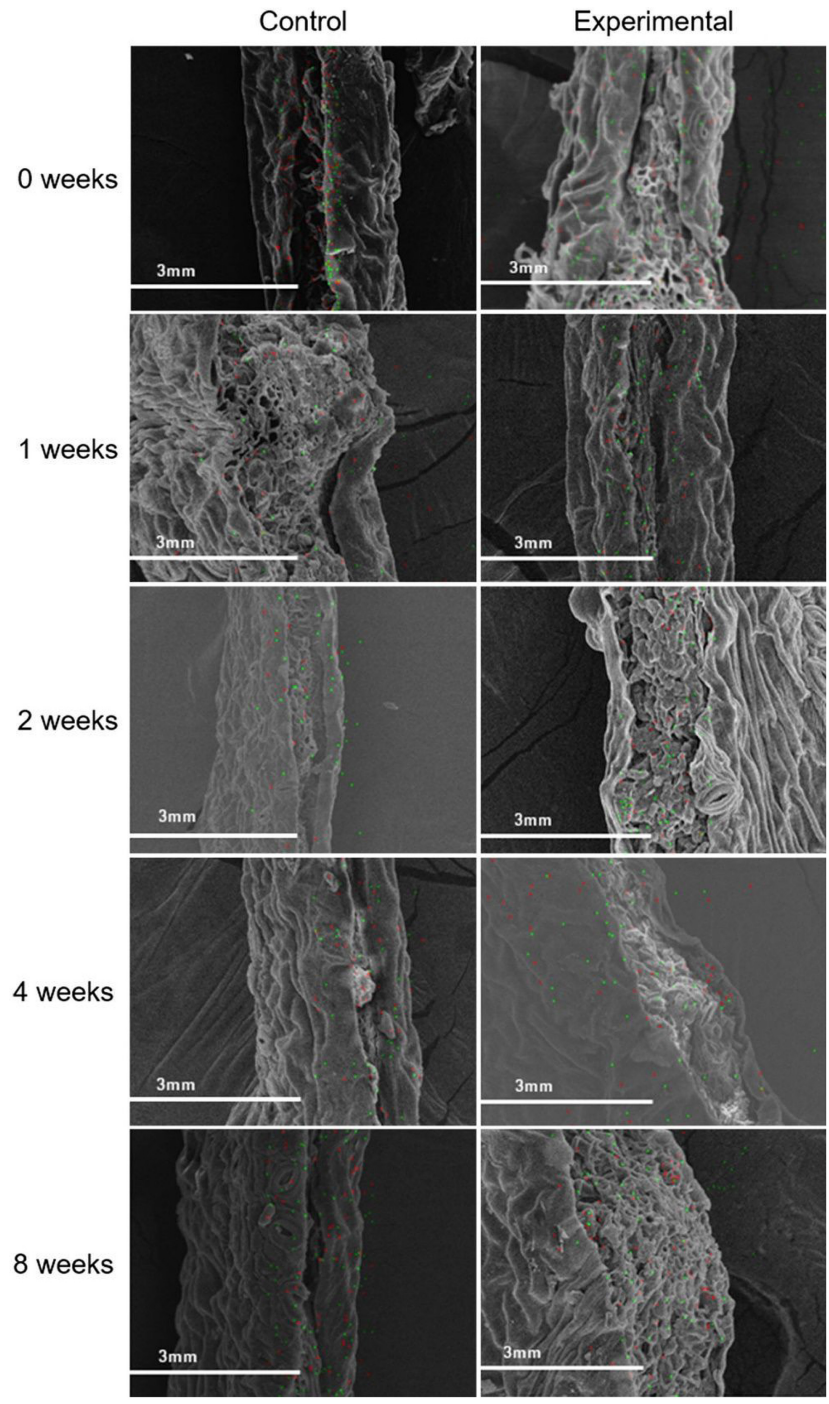

$20.6 \pm 3.4 \%$, respectively, compared with week 0 (Fig. 2 and Supplementary Table S2 ${ }^{1}$ ). However, content of Ca and $\mathrm{Mg}$ of leaf sides in the nutrient treatment leaf increased by $33.7 \pm 3.6 \%$ and $31.5 \pm 4.2 \%$, respectively, when compared with week 0 . At week 2 , Ca and $\mathrm{Mg}$ of leaf sides in controls increased by $28.5 \pm 2.5 \%$ and $29.2 \pm 2.8 \%$, respectively, whereas the amount of leaf sides in the nutrient treatment leaf increased by $36.3 \pm 2.7 \%$ and $37.0 \pm 3.4 \%$, respectively. At week 4 , Ca and $\mathrm{Mg}$ of leaf sides in controls increased by $21.0 \pm 3.1 \%$ and $21.9 \pm 3.6 \%$, respectively, and the content of leaf sides in the nutrient treatment leaf increased by $41.1 \pm 2.9 \%$ and $42.1 \pm 2.7 \%$, respectively. Finally, at week 8, Ca and $\mathrm{Mg}$ increased by $13.0 \pm 2.1 \%$ and $13.7 \pm 2.4 \%$ of leaf sides in controls, and $19.2 \pm 2.7 \%$ and

${ }^{1}$ Supplementary data are available with the article at https://doi.org/10.1139/cjps-2020-0271. 
Fig. 4. Analysis of the absorption rates of $\mathrm{Ca}^{2+}$ and $\mathrm{Mg}^{2+}$ content in petioles, adaxial, abaxial, and leaf side after spraying with nanosized plant nutrients. Each value was statistically compared with the control. cps/eV, counts per second per electron-volt, the elements in the composite mass, visualized counted in seconds per electron-volt. **Above the bars denote statistical significance at $P<0.01$, based on Dunnett's test.

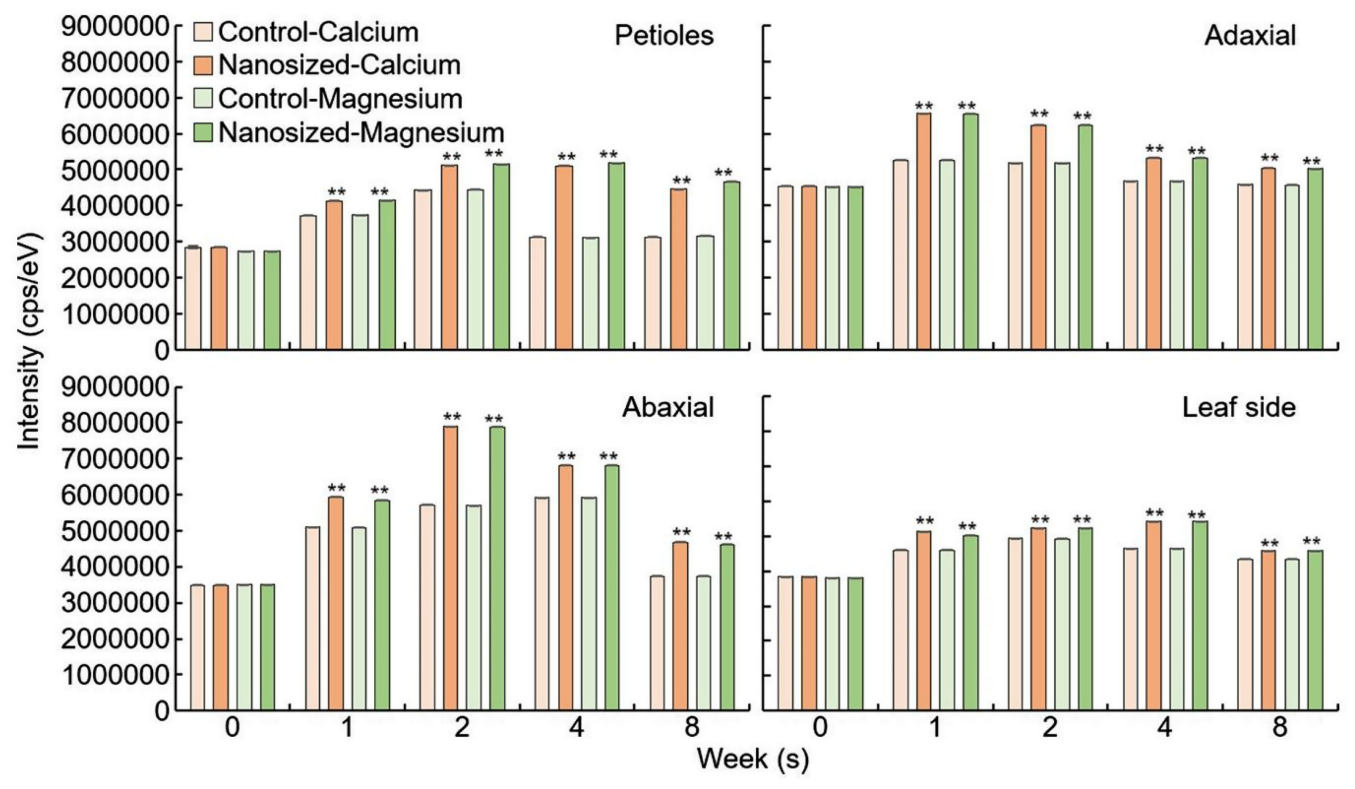

$20.1 \pm 1.8 \%$ of leaf sides in the nutrient treatment leaves, respectively.

\section{Leaf side}

Calcium and Mg contents in week 1 of controls were $46.4 \pm 2.4 \%$ and $45.6 \pm 3.1 \%$, respectively (Fig. 3 and Supplementary Table S3 ${ }^{1}$ ). Calcium and $\mathrm{Mg}$ contents at week 1 in the nutrient treatment leaves were $70.2 \pm 2.8 \%$ and $66.9 \pm 6.4 \%$, respectively, which was higher when compared with controls. At week 2, Ca and $\mathrm{Mg}$ in controls increased by $64.0 \pm 2.9 \%$ and $63.2 \pm 3.8 \%$, whereas in nutrient treatment leaf, the content increased by $126.5 \pm 3.5 \%$ and $125.5 \pm 4.9 \%$, respectively. At week 4, Ca and $\mathrm{Mg}$ in controls increased by $69.7 \pm 5.4 \%$ and $69.1 \pm 2.8 \%$, respectively, whereas in the nutrient treatment leaves, the content increased by $95.5 \pm 3.9 \%$ and $94.9 \pm 3.2 \%$, respectively. Finally, at week 8, Ca and $\mathrm{Mg}$ in controls increased by $7.2 \pm 2.7 \%$ and $6.7 \pm 1.9 \%$, respectively, whereas the content in the nutrient treatment leaves increased by $34.3 \pm 2.4 \%$ and $32.0 \pm 2.5 \%$, respectively.

Comparing week 0 with weeks 1 to 8 on the leaf side, $\mathrm{Ca}$ and $\mathrm{Mg}$ contents were higher in all nutrient treatments sprayed leaves (Fig. 4).

\section{Discussion}

Genetically superior varieties of fruit do not always have excellent taste, but the method of cultivation and environmental factors contribute to the content of sugar, size, and color (Khot and Sankar 2019). Providing plants with nutrients at the right time can produce better fruit. In such situations, nutrients can be applied via foliar fertilization. The purpose of foliar fertilization is to increase the absorption rate of nutrients for rapid recovery when plant nutrients are deficient. Plants absorb foliar nutrients via a combination of diffusion through stomatal channels, permeation through fine passages developed in epidermal cells, and electrical attraction of epidermal cell layers (Patil and Chetan 2018). Therefore, since the epidermal cells of the leaves are formed under the cuticle, if the substance used at the time of foliar application penetrates the cuticles, it can be completely absorbed. Wet nano pulverization reduces the particle size of calcium and magnesium while increasing the surface area. The decreased size and increased surface area of the delivery vehicle increases the absorption of these nutrients (Park et al. 2013; Lee et al. 2018). In addition, these nano sized phytonutrients particles prepared by physical or chemical methods have an increased mass to surface ratio, and nutrient introduction into the plant is effective (Subramanian and Tarafdar 2009). In this study, nano sized Ca and $\mathrm{Mg}$ particles were foliarly applied to peach tree leaves. Calcium and $\mathrm{Mg}$ contents increased after week 1, 2, 4, and 8 compared with controls.

The storability of fruits including peaches is closely related to the hardness of the cell wall (Khademi and Ershadi 2013). Fruits undergo a softening process that sharply decreases firmness after maturation and the cell wall collapses from this softening process (Wei et al. 2010). Calcium and $\mathrm{Mg}$ strongly bond with pectin in the cell wall and keep the structure of the cell wall firm 
(Jain et al. 2019). However, when Ca and Mg are insufficient, the cell wall readily collapses, promotes softening of the tissue, and causes reduced shelf-life. To improve the storage capacity for a long time after harvesting the fruit, the hardness of the cell wall must be maintained for a long time. Our results are consistent with other studies on the absorption rate of $\mathrm{Ca}$ and $\mathrm{Mg}$ components with nano sized particles (Park et al. 2013; Yoo et al. 2016).

When $\mathrm{Ca}$ and $\mathrm{Mg}$ are absorbed via the roots, into the plant, movement via the xylem is slow to the leaves and fruit, which can result in nutrient deficiency (Hossain et al. 2002). However Ca and Mg nano sized particles markedly increased absorption and migration in plants (Liu et al. 2005). When a plant is deficient calcium, the transport of sucrose and starch to the fruit of the plant is hindered, and the fruit becomes very vulnerable to pathogens (Elmer et al. 2007; Navrotsky 2004). Also, Mg deficiency reduces the content of chlorophyll and leaves change to a brown color (Serrano et al. 2004). Therefore, $\mathrm{Ca}$ and $\mathrm{Mg}$ are essential factors that need to be maintained at a constant level in plants. Calcium and $\mathrm{Mg}$ are important components that increase storage ability by maintaining the freshness of the fruit for a long time, but it is difficult for plants to absorb and accumulate these nutrients because of reduced movement within the plant.

In the present study, the results of absorption of nano sized particles in peach leaves shows a means of increasing content of $\mathrm{Ca}$ and $\mathrm{Mg}$ in peach leaf. Nano sized particles of nutrients can be effectively used to develop strategies for plants to rapidly manage $\mathrm{Ca}$ and $\mathrm{Mg}$ deficiencies (Sultan et al. 2009). Thus, we demonstrated that reducing the particle size of the plant nutrients to less than $900 \mathrm{~nm}$ increased the leaf content of $\mathrm{Ca}$ and $\mathrm{Mg}$. Nano sized plant nutrients applied increase the absorption rate of nutrients and may effectively be used to improve crop management.

\section{Conflicts of Interest}

The authors declare no conflicts of interest to report.

\section{Acknowledgements}

This work was supported by a grant from the New Breeding Technologies development Program (project no. PJ016531012022), Rural Development Administration, Republic of Korea.

\section{References}

Ajender, T.B., and Chawla, W. 2019. Effect of calcium chloride on growth, fruit quality and production of apple. J. Pharmacog. Phytochem. 1: 588-593.

Bansiwal, A.K., Rayalu, S.S., Labhasetwar, N.K., Juwarkar, A.A., and Devotta, S. 2006. Surfactant-modified zeolite as a slow release fertilizer for phosphorus. J. Agri. Food Chem. 54: 4773-4779. doi:10.1021/jf060034b.

Behboudi, F., Tahmasebi-Sarvestani, Z., Kassaee, M.Z., Modarres-Sanavy, S.A.M., Sorooshzadeh, A., and Mokhtassi-
Bidgoli, A. 2019. Evaluation of chitosan nanoparticles effects with two application methods on wheat under drought stress. J. Plant Nutr. 42: 1439-1451. doi:10.1080/01904167.2019. 1617308.

Christensen, L.P., Swanson, F., and Jensen, F.L. 1976. Waterberry studies in table grapes, Report of Research for Fresh Table Grapes. Vol. IV, California Table Grape Comm., Fresno, CA, USA.

Chung, H.S., Kim, J.K., Kang, W.W., Youn, K.S., Lee, J.B., and Choi, J.U. 2002. Effect of nitric oxide pretreatment on quality of MA packaged peaches. Korean J. Food Sci. Technol. 34: 1018-1022.

De Oliveira, J.L., Campos, E.V.R., Bakshi, M., Abhilash, P.C., and Fraceto, L.F. 2014. Application of nanotechnology for the encapsulation of botanical insecticides for sustainable agriculture: Prospects and promises. Biotechnol. Adv. 32: 1550-1561. doi:10.1016/j.biotechadv.2014.10.010. PMID:25447424.

Elmer, P.A.G., Spiers, T.M., and Wood, P.N. 2007. Effects of preharvest foliar calcium sprays on fruit calcium levels and brown rot of peaches. Crop Prot. 26: 11-18. doi:10.1016/ j.cropro.2006.03.011.

Farhat, N., Elkhouni, A., Zorrig, W., Smaoui, A., Abdelly, C., and Rabhi, M. 2016. Effects of magnesium deficiency on photosynthesis and carbohydrate partitioning. Acta Physiol. Plant. 38: 145. doi:10.1007/s11738-016-2165-Z.

Gao, Q., Xiong, T., Li, X., Chen, W., and Zhu, X. 2019. Calcium and calcium sensors in fruit development and ripening. Sci. Hortic. 253: 412-421. doi:10.1016/j.scienta.2019.04.069.

Girardi, C.L., Corrent, A.R., Lucchetta, L., Zanuzo, M.R., Costa, T.S.D., and Brackmann, A. 2005. Effect of ethylene, intermittent warming and controlled atmosphere on postharvest quality and the occurrence of woolliness in peach (Prunus persica cv. Chiripa) during cold storage. Postharvest Biol. Technol. 38: 25-33. doi:10.1016/j.postharvbio.2005.05.007.

Hossain, K.Z., Monreal, M., and Sayari, A. 2002. Controlled release of a plant growth regulator, $\alpha$-naphthalene acetate from the lamella of $\mathrm{Zn}-\mathrm{Al}$ layered double hydroxide complex. J. Controlled Release, 8: 417-427.

Jain, V., Chawla, S., Choudhary, P., and Jain, S. 2019. Post-harvest calcium chloride treatments influence fruit firmness, cell wall components and cell wall hydrolyzing enzymes of Ber (Ziziphus mauritiana Lamk.) fruits during storage. J. Food Sci. Technol. 56: 4535-4542. doi:10.1007/s13197-019-03934-z. PMID:31686685.

Jo, M.H., Ham, I.K., Park, K.S., and Cho, J.H. 2020. Effect of LED light intensity on seedling quality and tuber production of potato stem cuttings grown in a closed-type plant production system. Korean J. Crop Sci. 65: 468-476.

Lee, K.H., Park, J.H., Lee, Y.J., Ban, K.E., Jang, H.J., and Choi, J.H. 2013. Application of hot air for shelf-life extension of peach (Prunus persica L. Batsch). Korean J. Food Nutr. 26: 731-736. doi:10.9799/ksfan.2013.26.4.731.

Lee, S.H., Lee, S.M., So, S.J., Choi, Y.S., Kim, K.M., and Chung, I.K. 2018. Influence of enzymatic agents on the ginkgo fruit ratio using nano-processing technology. Inter. J. For. Hortic. 4: $16-24$.

Liu, X., Zhao-bin, F., Fu-dao, Z., Shu-qing, Z., and XU-sheng, H.E. 2005. Study on adsorption and desorption properties of nano-kaoline to nitrogen, phosphorus, potash and organic carbon. J. Sci. Food Agric. 38: 102-109.

Lurie, S., and Crisosto, C.H. 2005. Chilling injury in peach and nectarine: A review. Postharvest Biol. Technol. 37, 195-208. doi:10.1016/j.postharvbio.2005.04.012.

Khademi, Z., and Ershadi, A. 2013. Postharvest application of salicylic acid improves storability of peach (Prunus persica cv. Elberta) Fruits. Inter. J. Agric. Crop Sci. 5: 651.

Khot, D.S., and Sankar, M. 2019. Food (fruit) quality recognition by external appearance and internal flavor factors. Globe, 6. 
Kraemer, T., Hunsche, M., and Noga, G. 2009. Selected calcium salt formulations: Interactions between spray deposit characteristics and Ca penetration with consequences for rain-induced wash-off. J. Plant Nutr. 32: 1718-1730. doi:10.1080/01904160903150958.

Krishna, B.S., Murty, D.S.R., and Prakash, B.S.J. 2001. Surfactant modified clay as adsorbent for chromate. Appl. Clay Sci. 20: 65-71. doi:10.1016/S0169-1317(01)00039-4.

Manganaris, G.A., Vasilakakis, M., Mignani, I., Diamantidis, G., and Tzavella-Klonari, K. 2005. The effect of preharvest calcium sprays on quality attributes, physicochemical aspects of cell wall components and susceptibility to brown rot of peach fruits (Prunus persica L. cv. Andross). Sci. Hortic. 107: 43-50. doi:10.1016/j.scienta.2005.06.005.

Mohammadinejad, R., Karimi, S., Iravani, S., and Varma, R.S. 2016. Plant-derived nanostructures: types and applications. Green Chem. 18: 20-52. doi:10.1039/C5GC01403D.

Nano Science Biotech Co Ltd. 2016. The Insoluble calcium and magnesium as a active ingredient flower thinning agent, Korea. Patent registration number 10-1629387.

National Academy of Agricultural Science (NAAS). 2010. RDA. Standard fertilization by crop. pp. 184-187.

Navrotsky, A. 2004. Environmental nanoparticles. Pages 1147-1155 in Schwarz, C.I. Contescu, eds. Dekker encyclopedia of nanoscience and nanotechnology, Vol. 2. New York.

Park, S.G., Kwon, S.J., Kim, Y.M., and Lee, S.S. 2013. Reaction properties of non-cement mortar using ground granulated blast furnace slag. J. Korea Cont. Assoc. 13: 392-399. doi:10.5392/JKCA.2013.13.09.392.

Patil, B., and Chetan, H.T. 2018. Foliar fertilization of nutrients. Marumegh, 3: 49-53.

Prabakaran, G., Vaithiyanathan, D., and Ganesan, M. 2018. Fuzzy decision support system for improving the crop productivity and efficient use of fertilizers. Comput. Electron. Agric. 150: 88-97. doi:10.1016/j.compag.2018.03.030.

Ruoyi, K., Zhifang, Y., and Zhaoxin, L. 2005. Effect of coating and intermittent warming on enzymes, soluble pectin substances and ascorbic acid of Prunus persica (Cv. Zhonghuashoutao) during refrigerated storage. Food Res. Int. 38: 331-336. doi:10.1016/j.foodres.2004.09.015.

Serrano, M., Martínez-Romero, D., Castillo, S., Guillén, F., and Valero, D. 2004. Effect of preharvest sprays containing calcium, magnesium and titanium on the quality of peaches and nectarines at harvest and during postharvest storage. J. Sci. Food Agric. 84: 1270-1276. doi:10.1002/jsfa.1753.

Sohail, M., Ayub, M., Khalil, S.A., Zeb, A., Ullah, F., Afridi, S.R., and Ullah, R. 2015. Effect of calcium chloride treatment on post-harvest quality of peach fruit during cold storage. Inter. Food Res. J. 22: 2225-2229.
Song, S.J., Kim, Y.R., Han, S.G., and Kang, Y.G. 2006. Foliar absorption rates of $45 \mathrm{Ca}-\mathrm{labeled}$ calcium compounds applied on tomato and citrus leaves. Korean J. Soil Sci. Fert. 39: 80-85.

Subramanian, K.S., and Tarafdar, J.C. 2009. Nanotechnology in soil science. Proc. of the Indian society of soil scienceplatinum jubilee celebration, 22-25 Dec. IARI, Campus, New Delhi. pp. 199.

Sultan, Y., Walsh, R., Monreal, C., and DeRosa, M.C. 2009. Preparation of functional aptamer films using layer-by-layer self-assembly. Biomacromolecules, 10: 1149-1154. doi:10.1021/ bm8014126.

Tabak, M., Lisowska, A., Filipek-Mazur, B., and Antonkiewicz, J. 2020. The effect of amending soil with waste elemental sulfur on the availability of selected macroelements and heavy metals. Processes, 8: 1245. doi:10.3390/pr8101245.

Uchida, R. 2000. Essential nutrients for plant growth: nutrient functions and deficiency symptoms. Plant Nutrient Manage. Hawaii's Soils, 31-55.

Wang, X., Yang, Z., Liu, X., Huang, G., Xiao, W., and Han, L. 2020. The composition characteristics of different crop straw types and their multivariate analysis and comparison. Waste Manage. 110: 87-97. doi:10.1016/j.wasman.2020.05.018.

Wei, J., Ma, F., Shi, S., Qi, X., Zhu, X., and Yuan, J. 2010. Changes and postharvest regulation of activity and gene expression of enzymes related to cell wall degradation in ripening apple fruit. Postharvest Biol. Technol. 56: 147-154. doi:10.1016/ j.postharvbio.2009.12.003.

Wolf, J., Straten, S., Pitann, B., and Mühling, K.H. 2019. Foliar magnesium supply increases the abundance of RuBisCO of Mg-deficient maize plants. J. Appl. Bot. Food Quality, 92: 274-280.

Yan, D.M., Guo, Z.H., Huang, F.L., Ran, H.Z., and Zhang, L. 2020. Effect of calcium magnesium phosphate on remediation paddy soil contaminated with cadmium using lime and sepiolite. Huanjing kexue, 41: 1491-1497. PMID:32608653.

Yamane, T., Hayama, H., Mitani, N., Inoue, H., and Kusaba, S. 2020. Contribution of several fruit quality factors and mineral elements to water-soaked brown flesh disorder in peaches. Sci. Hortic. 272: 109523. doi:10.1016/j.scienta.2020. 109523.

Yoo, J.G., Kan, B.K., Kim, D.H., Lee, J.W., Lee, D.H., et al. 2016. Effect of flower and fruit thinner on fruit set and fruit quality of 'Gamhong' apples. Korean J. Hortic. Sci. Technol. 34: 24-31.

Zabkiewicz, J.A. 2002. Adjuvants and herbicidal efficacy present status and future prospects. Weed Res. 40: 139-149. doi:10.1046/j.1365-3180.2000.00172.x. 